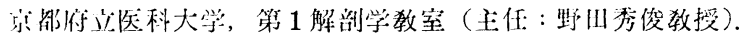

Anat. Inst. d. Med. Akad. d. Kyoto-präfektur (Dept. of Anat.; Kyoto

Prefectural Medical College) (Vorstand: Prof. Dr. H. NODA).

\title{
視床下部下垂体系における神膠性要素の 染色性に関する檢討.
}

(視休下部下垂体系の比較組織学的研究。第 24 報.)

\section{Über die Färbbarkeit der neurogliösen Elemente des}

Hypothalamus-Hypophysensystems.

(Beiträge zur vergleichenden Histologie des Hypothalamus-

Hypophysensystems. 24. Mitteilung.)

斎藤修, 中川幸英, 隠岐宗達.

Osamu SAITO, Yukihide NAKAGAWA u. Sōtatsu OKI.

[昭和 31 年 8 月 22 日煌稿受付.]

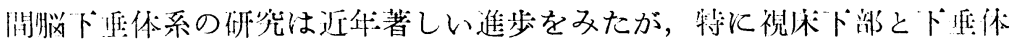
との問の神経体液性協関の問題を研究するとあたって, 神経線維队び血管 系統の研栄にその主力が注がれ, 他の要素が比輷的等䦥に附せられている 様な感がある。特に視床下部下垂体系の神膠性要素飞関しては今日迄，そ の染色技術の困難さと相まって, 追究さるるところ最も少く, この部の神 膠性要素の研究は, 主として後葉が神経線維を含むか否か, 或いはその内 部飞見られる線維が神膠性であるか結合組織性であるかという議論の盛ん であった 1920 年以後，多んど兒るべき進步をもたらしていない現状であ る。我々は神経分泌之の関連に招いて視床下部下垂体系に括ける神膠性岁 索の一般的形態を観繁するために, 光ずその染色性の検討を試みた。 今日 までこの方面の研究に用いられた主なる染色法をるると，最初に神経性下 垂体の神膠性要素の存在を主張した人々，即ち Lothringer（1886）, Berklev (1894), Retzius (1894), Trau1mann（1909）管は主として Golgi 添を

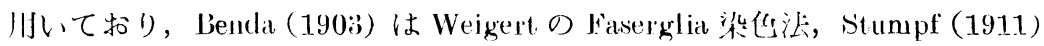
は Fieandt 法, Hoenig (1922) は Sichultze-Stöhr O Natronlauye-Silbermothode, Scheele (1929) は Holzer 法等を使用している。こ北らの人々は

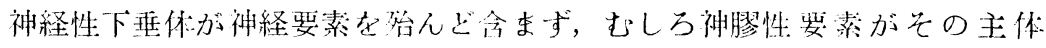

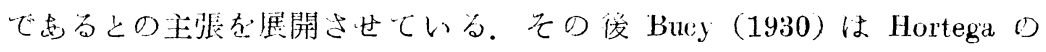
Mikrogliazellen 及び Oligodendrogliazellen 鍍銀法の Penfield 変法を使用

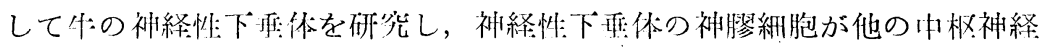

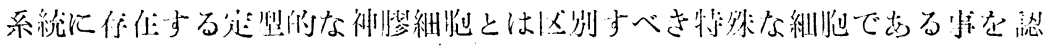


め, これを Pituizyten 後葉細胞と命名し, Benda（1932）もHortega 法に

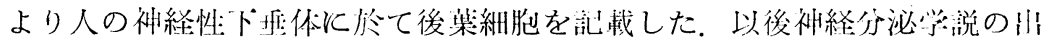

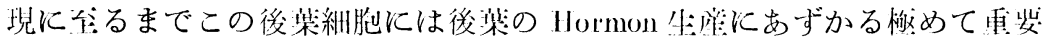
な分泌細胞としての役制が势られ，Romeis（1940）は Möllendorff の Handbuch の Hypophyse の中で後染細胞の一種である Adenopituizyten に 分泌所罗を認めている。.Bucy 以後一般に後㷊細胞の証明にはPenfield 変 法又は Hortegas Silbercarbonat 法 (Oligodendroglia のための) 等が最もよ く使用せられているが，Nowakowski (1951) は猫では Cajal の Bromsilber 法, Hortega の Astrozyten 法, 更飞 Faserglia には Holzer 法, Reumont 法などが好結果をもたらすと報告している.

以上の如く一般に Hortega 法を主体とする定型的神翏細胞の鍍銀法のい ずれもが後葉細胞の証明にも使用せられる。換言すればそのいずれもが後 葉紐胞の特晎的鍍銀法にはなり得ない事を示している。我々が犬，猫及び

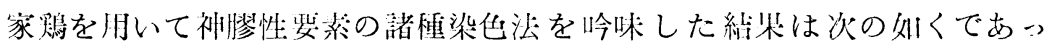
た.

\section{I. 材 料と方 法.}

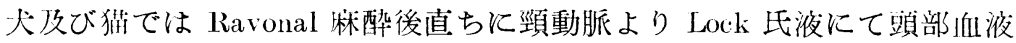
を還流し，所定の固定液を注大，直ちに開頭し視床下部と下垂体を一体と

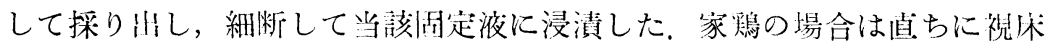
下部下垂体系を摘出して固定した。 Penfield，䄑村等が注意する如く，神 膠性要素の所見或いは鍍銀の成果は死後時間と固定液の迅速な浸透に影慜 される所が人きい，我々の例では全て死彴30分をこえなかった。

使用した染出法灭び鍍銀法は Rio-Hortega 9 protoplasmatische und faserige Neuroglia のための Silbercarbonat 法 (4. Modifikaition) (1917), Oligodendroglia のための Silbercarbonat 法 (1921), 队び Mikroglia (drittes Element) のための Silbercarbonat 法 (1921), F. Cardillo 法 (1929),

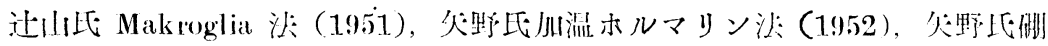

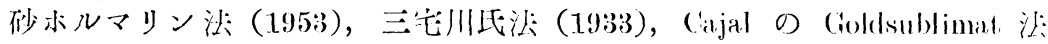
(1926), Penfield $の$ zweite Molifikation (1928), Reumont 涪; Holzer 0 Gliafaser 染色法 (1921), Mallory の Phosphorwolframhïmatoxylin 染色 法 (1901)，Severinghaus 染色法（1932），Kraus 染色法（1914）, Azan 染 色法 (1915), Gomori (CHP) 染色法 (1939) 及び Hämatoxylin-Eosin 染色 法の諸法である。

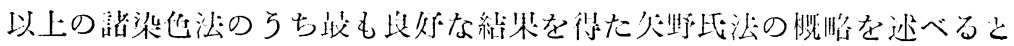


次の如くである。

1. 矢野氏加温ホルマリン法（1952）.

本法は人の Mikroglia 及び Oligodendroglia の証明に適すると報告せら

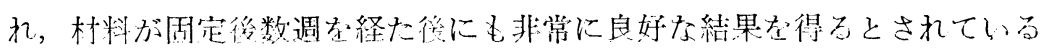
ものであろ。

1. 固定, $10 \%$ ホルマリン水.

2. 凍結切片作製.

3. 1 -2 秒間莈溜水で水流.

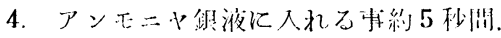

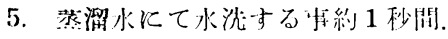

6. $20 \%$ 中性木ルマリン水で $40^{\circ}-58^{\circ} \mathrm{C}$ 飞保ちつつ羁元する求約 1 分開.

7. その後型の则く鍍金する.

2. 矢野氏嗍砂ホルマリン法 (1953).

本法は材料が新鮮であることを要し，人の Mikroglia 及び Oligodendroglia の証明及び病的 Makroglia の証明に適するとされているものである.

1. 固定は10\%単純ホルマリン水のみで行う。

2. 凍結切片作製。

3. $2-3$ 秒間蒸溜水で水沙.

4. アンモニヤ銀液飞入れる事約 5 秒間.

5. 蒸溜水飞て水洗する事約 1 秒間.

6. 嗍砂ホルマリン水とて罡元する事数 10 秒閒, 約 $30^{\circ}-32^{\circ} \mathrm{C}$ で行う（ホルマリ $>2 \mathrm{cc}+\mathrm{Aq}$. dest. $98 \mathrm{cc}+$ Borax $0.1 \mathrm{~g}$ ).

7. その後型の如く鍍全する。

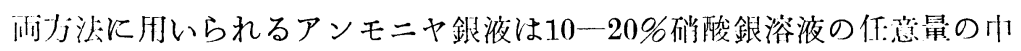

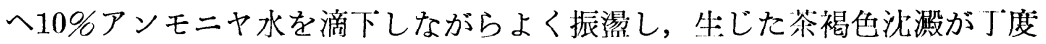
溶解し去つた所で止める。この液は1-2年間保存飞附える，硝酸銀溶液の 濃度と還元するホルマリン水濃度との関係については，20\%硝酸銀溶液の 使用に際しては同様に $20 \%$ ホルマリン水で還元するのが結果よりみてよ く, 又10\%硝酸銀溶液よりも20\%硝酸銀溶液を使用する方が鍍金が強く行 われると矢野氏は教えている，尚，通常固定に用いる中性ホルマリン水は 岑酸カルンウムで中和を行つているが，硼酸と $\mathrm{NaOH}$ を用いた緩衝液で pH 7.2 飞中和すると神経線維が共染して神膠細胞の研究とは適しない事を

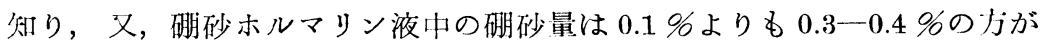

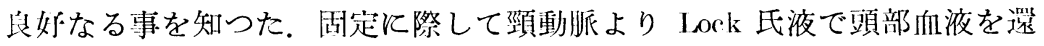
流せる後固定液を注入したものと, 死後直ちに㓣定液に入れたものの閒に は，鍍銀性及びその所見飞差異が認められず，周定月数は 2-20日閌の種 々のものを用いたが鍍銀性は認もべき変化を是しなかった。 


\section{II. 所見.}

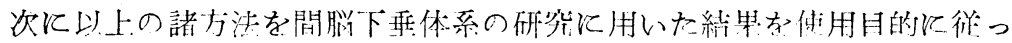

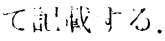

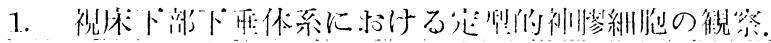

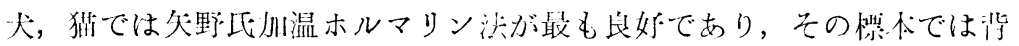
景は淡灰色を是し，乙かも沈測物様銀顆粒等の人丁库物の企ずる事なく，

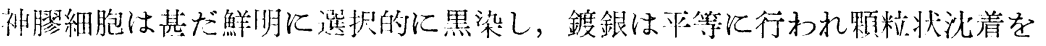
涊めない，伅管系との関係をみるには Cajal の Goldsublimat 法が妒結果

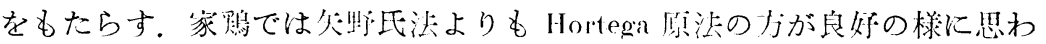
れる。

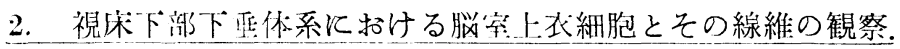

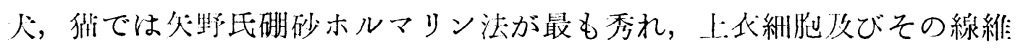

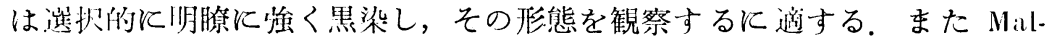

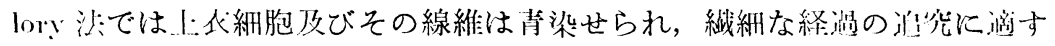

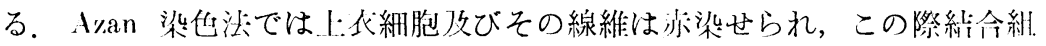
織は青染するために沙者の関係を観察するによく, Severinghaus 法では、I: 代細胞队びその線維は fuchsinrot となり，一才，結合組織は緂色を旱する ため，これまた阔者の関係をらかがうに適する。尚，边忯法も非常に明

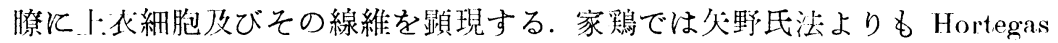
Oligodendroglia 鍍銀法のうが良好である。.1代線維は神絴線維鍍銀法, 例

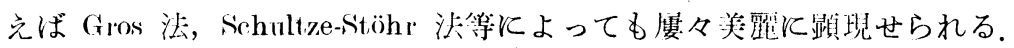

3. Aussere und innere Gliafaserdeckschicht 队び Membrana limitans gliae perivascularis の観察.

これとは Holzer 法が最も秀れ，䋊紏な Gliafaser にいたるまで明䐲に 紫青色飞染まる。 その他 Mallory 法, Azan 染出法, Gomori (CHP) 染也 法でもその大略が認められる。

\section{4. 後葉細胞の観察.}

犬，猫では矢野氏嗍砂ホルマリン法が最も良好であり，後葉紼胞は紫色 を带びた黒色を呈し，甚だ明膫にしか子選択的に鍍銀される。原形質万び 笑起に比しては核は幾分好銀性が弱い，家鴊では矢野氏法よりもHortegas Oligodendroglia 鍍銀法の方が秀れている。その他一般に Azan 染色法では 後柴細胞は赫染し， Severinghaus 法では原形質队び核の状態が明らかであ

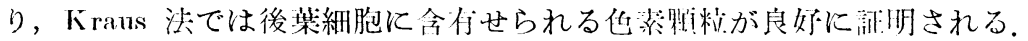

(与真は㙮続諸報に揭載与る。) 


\section{III. 結語.}

以上を要約すれば次の如くである。

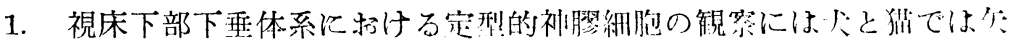
野氏加温ホルマリン法，家鴊では Hortega 原法が適する。

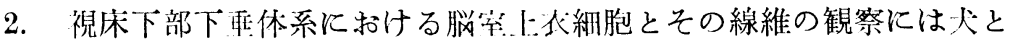

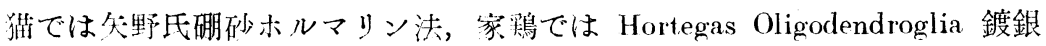
法, その他一般に Mallory 法, Azan 染色法, Severinghaus 法, 过低法, Gros 法, Schultre-Stöhr 法が阅する.

3. Cussere und innere Gliafaserdeckschicht 乃び Membrana limitans gliae perivascularis の観察には Holzer 法が適する.

4. 後葉細胞の観察には犬と猫では矢野氏硼砂ホルマリン法, 家鴊では Hortegas Oligodendroglia 鍍銀法，その他一般に Azan 染色法. Severinghaus 法, Kraus 法が適する。

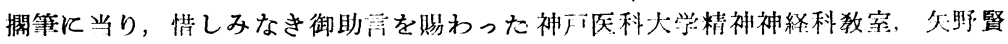
治数授飞対し篤く感謝の熟を表明致します。

\section{Autoreferat.}

Um eine Vorbereitung zu der histologischen Untersuchung über die neurogliösen Elemente des Hypothalamus-Hypophysensystems zu machen, wurden verschiedene Färbungen desselben mit Silber und Farbstoffen vorgenommen. Für die Beobachtung der typischen Neurogliazellen im Hypothalamus-Hypophysensystem erwiesen sich hei Hund und Katze die YANOsche Warmformalinmethode, bei Haushuhn die HORTHGAsche Originalmethode als die beste. Für die Ependymzellen und -Fasern waren bei Hund und Katze die YANOsche Borax-Formalinmethode und bei Haushuhn die HOR'TEGAsche Methode für Oligodendroglia die besten. Auch die Methoden nach MALLORY, SEVERINGHAUS, TSUJIYAMA, GROS, SCHULTZE-STÖHR und die Azanmethode waren gut brauchbar. Zur Darstellung der inneren und äußeren Gliafaserdeckschicht und der Membrana limitans gliae perivascularis war die HOLZERsche Methode die beste. Für die Pituizyten waren bei Hund und Katze die YANOsche Borax-Formalinmethode und bei Haushuhn die HORTEGAsche Methode für Oligodendroglia die besten. Auch die Azanmethode, die SEVERINGHAUSsche und die KRAUSsche Methode waren brauchbar. Die Ergebnisse werden in nachfolgenden Mitteilungen durch Photos veranschaulicht. 


\section{文献。}

Benda, C. : Handbuch der pathologischen Anatomie des Nervensystems. 1903. Handbuch der inneren Sekretion, hrsg. von M. Hirsch. 1932. S. 867. - Berkley, I1. J.: Johns Hopkins Hosp. Rep. 4 (1894). P. 117 a. 285. Zit. n. Romeis (1940),

- Bucy, P. C. : .J. comp. Neur. 50 (1930). P. 505. Cajal, R. y.: 7. Neur. u. Psych., 100 (1926). S. 738. Cardillo, F.: Rivista patolog. nerv. e mentale. 46 (1929). - Holzer, W. : Z. Psych., 77 (1921). S. 358. - Kraus, E.J. : Virchows Arch. 218 (1914). S. 107. - Lothringer, S.: Arch. mikr. Anat. 28 (1886). S. 257. Mallory, F. B. : Zit. n. Romeis (1948). 一它川廉平：京府医大就. 9 (1933). 頁 217. Nowakowski, H. : I)t.seh. Z. Nervenhk. 165 (1951). S. 261. ‥ Penfield, W.: Amer. J. Path. 24 (1928). s. 117. - Retzius, Y.: Biol. Intersuch., Neue Folge. 6 (1894). S. 21. Zit. n. Romeis (1940). - Rio-Hortega, P. del.: Trab. Jab. Invest. Biol. Univ. Madrid. 15 (1917). P. 367. - Mem. R. Soc. Exp. Hist. Nat. 11 (1921). S. 213. - Archivos de Neurobiologia. 2 (1921). P. 1. Zit. n. Romeis (1948). - Romeis, B.: Handbuch der mikroskopischen Anatomie des Menschen, hrsg. von Möllendorff. Bd. 6, Tl. 3. Innersekretorische Drüsen. III. (1940). S. 625. - Mikroskopische Technik. Leibniz Verlag, 1948. - Scheele, H. : J. Psych. u. Neur. 40 (1929). S. 70. - Severinghaus, A.: Anat. Rec. 53 (1932). P. 1. - Stumpf: Virchows Arch. 206 (1911). S. 70. - Trautmann, A.: Arch. mikr. Anat. 74 (1909). S. 311. - 辻山義光 : 脳と神経. 3 (1951). 頁 259. 一 Y ano, K. : Fol. Psych. Neur. Jap. 5 (1952). P. 181. 一精神触経志. 55 (1953). 頁 528. 